\title{
Contradictions and challenges of fish slaughter in Brazil
}

\author{
Maria Clara Miguel Libanori ${ }^{1}$, Rafaela de Paula Casado ${ }^{2}$, \\ Marília Cristina Sola ${ }^{3}$, Paulo Fernandes Marcusso ${ }^{3 *}$
}

Received: Jan, 2019; Accepted: Jun, 2020

\begin{abstract}
Fish farming is an extremely important activity for the Brazilian market since it is currently on the rise. In order to obtain high-quality products, some care is necessary from the breeding, involving facilities, adequate feeding, handling, harvesting, slaughtering, and packaging. In the fish farming chain, one of the most important moments is the slaughtering, because it is when the product undergoes modifications that interfere in its final quality, considering appearance, odor, texture, and palatability. In the Regulation of Industrial and Sanitary Inspection of Products of Animal Origin (RIISPOA), there is little information that refers to the slaughter of fish, mainly about the appropriate way to be performed, and the Normative Instruction No. 3 of the Ministry of Agriculture, Livestock and Supply (MAPA) of January 17, 2000, determines the standardization of stunning methods to humane slaughter in various animal species, except for fish. According to this bibliographical review, stunning by electrocution, a lethal blow to the head, and the bone marrow section are the best techniques to be used, but there is still a lack of studies for standardization of methods. For this reason, this work gathers information about fish slaughter, as well as highlights the need for regulation by the relevant bodies.
\end{abstract}

Keywords: animal welfare, health legislation, fish farming, fish, quality.

\section{Introduction}

Fish farming is one of the activities that is expanding most in Brazil. From 2014 to 2019, there was an increase of 31\% (PeixeBR, 2020), both by

\footnotetext{
${ }^{1}$ AQUOS-Aquatic Organisms Health Laboratory, Aquaculture Department, Federal University of Santa Catarina (UFSC), Florianopolis, SC, Brazil

${ }^{2}$ State University of Maringa (UEM), Umuarama - Parana, Brazil

${ }^{3}$ Federal University of the Jequitinhonha and Mucuri Valleys (UFVJM), Institute of Agricultural Sciences, Unai - Minas Gerais, Brazil

*corresponding author: paulomarcusso@gmail.com, (+55 38) 99930 1988, Av. Universitaria, 1000. CEP 38610-000, Unaí, Minas Gerais
} 
freshwater reservoirs, which represent about $12 \%$ of the planet's reservoirs, the favorable climate, and the growing domestic market, since fish is a source of animal protein and essential nutrients of excellent quality (SEBRAE, 2015, FAO, 2006).

Brazilian farmed fish production reached 758,006 tonnes in 2019, 4.9\% more than in 2018. Tilapia maintains the lead within the most produced species, with 432.14 tonnes, consolidating Brazil as the fourth largest world producer of tilapia (PeixeBR 2020). For this reason, it is of great concern obtaining high-quality food and slaughter, with all its stages, is an essential factor for the final quality of the product (FERREIRA et al., 2018).

There is already anatomic, physiological, behavioral, evolutionary, and pharmacological evidence proving that fish are sentient beings - that is, they are aware of feelings - but it is still a little-explored subject for producers, consumers, and even in the current legislation (PEDRAZZANI, 2007).

This study aimed to gather relevant information on the techniques of stunning and slaughter of fish and to demonstrate the lack of standardization established by supervisory bodies in Brazil.

\section{Review}

Along with the growth of the Brazilian population in recent years, a healthier lifestyle is much sought-after, and one of the main options for food is fish. Due to the great demand, fish farming has advanced a lot in its production, and as extractive fishing is no longer able to meet the needs, the growth of cultivated fish is noticeable, and cattle farming activity is on the rise in Brazil (ANDRADE and YASUI, 2003).

Fish production had to be intensified to ensure this growth. Therefore the activity bottlenecks - such as the scarcity of private and institutional financial resources, water quantity and quality, environmental impact, 
stress during production, and opportunistic diseases - have emerged as the main barriers to national aquaculture (CREPALDI et al., 2006).

Stress is a set of responses of the animal body to unpleasant stimuli (FREIRE and GONÇALVES, 2013). The degree to which the quality attributes of meat are affected by stress depends on the severity, duration, and speed of the stressing agent, which can occur both through production management and through stocking density, transportation, and slaughter (LAMBOOIJ et al., 2002).

Stress, pre- and during slaughter, leads to an increase in respiratory rate, alarm pheromone production, and behavioral reactions such as escape, immobilization, change in rhythm and swimming pattern (PEDRAZZANI et al., 2007), which consequently cause a decrease in the fish's energy reserves, reducing the period of entry and exit of rigor mortis, and hence decreases the quality and shelf life of the product (FREIRE and GONÇALVES, 2013).

In addition to product quality, consumers are increasingly concerned about animal welfare, so it is also relevant to consider humane slaughter (FREIRE and GONÇALVES, 2013). Although fish slaughter is one of the leading causes of stress production, in this context, there is no specific legislation for it in Brazil (VIEGAS et al., 2012).

The World Organisation for Animal Health (OIE) is the intergovernmental organization responsible for improving animal health worldwide and the Aquatic Animal Health Code (OIE, 2012), chapter 7, contains information on the welfare of captive fish and recommendations on the transport, stunning, and slaughter of species for human consumption.

In transport, the producer is given responsibility for the general health status of the animals, welfare throughout the journey, and transport planning, besides vehicles adapted to each species transported; provision of trained staff for loading, unloading, and emergency slaughter if necessary; and the reduction of stress to the animals during the journey (OIE, 2012). 
According to Kubitza (2007), for the transport of live fish, some factors are relevant: properly fasting, reducing water temperature and ensuring its control, using salt in the transport water and oxygen support throughout the journey. In addition to this care in transportation, transporters should always revise pieces of equipment such as hoses, diffusers, flowmeters, magnetic meters, motor pumps, oximeters, among other equipment used (LOPES, 2012).

As for unloading, transport, and loading, the water must be analyzed before unloading and injured as well dying fish must be isolated or slaughtered. The handling of fish should be minimal to avoid stress. In equipment used for fish handling, it is necessary to reduce the risk of injury and to avoid prolonged fasting. According to Chicrala \& Santos (2013), the period for emptying the digestive tract of fish varies from 24 to 48 hours, depending on the species cultivated. For the accommodation facilities, it establishes the particularities of each species, taking into account the proportional size, slaughter capacity, and the reduction of injuries and stress for fish (OIE, 2012).

Stunning and slaughter techniques should correspond accordingly to the species and the information available. The way to check the effectiveness of stunning is by total loss of consciousness besides installing a spare stun device for fish that are regaining consciousness to be stunned again. The loss of consciousness is measured by the absence of body and respiratory movements, loss of Visual Evoked Potentials (VEP) and loss of Vestibule-Ocular Reflex (VOR) (OIE, 2012).

Mechanical stunning and slaughter methods are generally irreversible when applied correctly. It is also possible having fish stunning by percussion, which can be done manually or by specialized equipment, such as the dart gun, which is an irreversible stunning and slaughter method. For large fish, the use of a firearm is allowed as a strategy of stunning and slaughter (OIE, 2012). 
Electrical methods, such as stunning by electrocution, must present adequate intensity, frequency, and duration for each species, causing immediate loss of consciousness. However, this type of stunning can be reversible, requiring bleeding right after it (OIE, 2012).

There are also other methods of slaughter, such as thermal shock, the use of ice; exposure to carbon dioxide (CO2) in water; asphyxiation by removing the water, and bleeding without prior stunning. However, it has been shown these methods lead to a loss in fish welfare. (OIE, 2012).

These are some examples of humane methods of stunning and slaughter, according to the species (OIE, 2012):

1. Carp and salmonids: percussion or electrocution

2. Tuna: firearm or with a sharp object

3. Salmonidae: electrocution

On March 29, 1952, Decree No 30,691 was signed, which approved the Regulation of Industrial and Sanitary Inspection of Animal Products (RIISPOA), consolidating Brazil's first sanitary code. These norms have been adapted to other legislation, such as the Consumer Protection Code and the Decree establishing the Unified Agricultural Health Care System (SUASA) (BRASIL, 2017).

Subsequently, in 2017, Decree No. 9013 was established, updating the industrial and sanitary inspection of products of animal origin, aiming at

Animals intended for slaughter, meat, and meat products, fish and fish products, eggs and their derivatives are subject to the inspection and monitoring provided for in this Decree.

Single paragraph. The surveillance covers the ante and post-mortem inspection procedures, reception, handling, processing, industrialization, fractioning, preservation, packaging, labeling, storage, dispatch, and transit of any raw materials and products of animal origin. 
The Normative Instruction No. 3, of the Ministry of Agriculture, Livestock, and Supply (MAPA) (BRASIL, 2000) considers the need to standardize the methods of stunning to humane slaughter, determining minimum conditions for protection before and during animal slaughter, to avoid pain and suffering to butchers, poultry and wild animals raised in captivity. Topic 2 - definitions, clarifies that

Butchery animals: mammals (bovids, equids, pigs, sheep, goats, and rabbits) and poultry, as well as wild animals bred in captivity, slaughtered in establishments under veterinary inspection.

This regulation also provides that slaughter establishments must be equipped with appropriate technology, in addition to cover some measures to follow the parameters set by the sanitary authority: fish protection during unloading operations, waiting chamber and equipment for washing animals, installations and equipment for water treatment.

According to Lopes (2012), the installations meet the requirements of the type of system employed on the property, which may include tanks, weirs, nurseries, net-tanks, barges, for example. For that, it is necessary to have a suitable terrain, the ideal being flat or with a $5 \%$ slope, for a minimum movement of the land.

The ideal soil would be sandy or clayey, which are impermeable. The availability of water must be abundant to replenish losses due to evaporation, infiltration, and to allow the renewal of the tanks, in addition to being of good quality (LOPES, 2012).

Stocking density is a vital factor for animal welfare, since a highdensity area favors aggressiveness, causes injuries, and leads to the appearance of diseases and abnormal behavior. The adequate stocking density for fish depends on each species, as each one has its own behavior, such as territoriality and the tendency to form shoals (PEDRAZZANI, 2007). 
According to the RIISPOA (BRAZIL, 2017), only amphibians and reptiles should be inspected before slaughter. Authorization from the Federal Inspection Service to conduct slaughter procedures is mandatory, and it is prohibited to perform slaughter procedures without animal fasting, water diet, and rest, thus compromising animal welfare. Fish slaughter must include previous stunning followed by immediate bleeding. Slaughter methods for each species are to be established in complementary rules (BRASIL, 2017).

According to Pedrazzani et al. (2007), fish slaughter techniques are essential for animal welfare and a quality end product. The range of slaughtering types aims to improve the efficiency and safety of the procedures and the final quality control of the product.

An ideal slaughter method must be fast, easy, hygienic (FREIRE and GONÇALVES, 2013). For this purpose, it is important to reduce the time needed for death and to reduce emotions during the process. Some of the most practiced slaughter methods are electrical stunning, lethal blow to the head, thermal shock with ice for pre-slaughter stunning, bone marrow section, or water removal, causing death by asphyxiation (PEDRAZZANI et al., 2007).

Thermal shock with ice water (thermonarcosis) is one of the most widely used slaughter methods in marine and continental fish species, such as African catfish (Clarias gariepinus), grass carp (Ctenopharyngodon idella), sea bream (Sparus aurata), sea bass (Dicentrarchus labrax), salmon (Salmo salar), turbot (Psetta maxima) and rainbow trout (Oncorhynchus mykiss) (VIEGAS et al., 2012). Although this technique is easy and reasonable to carry out to preserve fish qualities, the procedure causes a slow death (MENDES et al., 2015).

For example, for rainbow trout (Oncorhynchus mykiss), the stunning takes between 28 to 198 minutes, for salmon (Salmo salar) approximately 60 minutes, for turbot (Psetta maxima) 20 minutes, for sea bream (Sparus 
aurata) 20 to 40 minutes, for sea bass (Dicentrarchus labrax) 20 minutes, and for eel (Anguilla anguilla) 12 minutes (VIEGAS et al., 2012). The evaluation of stunning methods relates to the speed of the technique; however, in the case of thermonarcosis stunning, some species of fish need 15 minutes or more under exposure, suffering osmoregulatory problems and exhaustion (FREIRE and GONÇALVES 2013).

Slaughter by immersion in saturated water with $\mathrm{CO}_{2}$ is mainly used in farmed salmon (Salmo salar), rainbow trout (Oncorhynchus mykiss), sea bass (Dicentrarchus labrax), common carp (Cyprinus carpio), eel (Anguilla anguilla) (VIEGAS et al., 2012). Freezing water saturated with $\mathrm{CO}_{2}$ is intended to be an anesthetic, causing reduced stress, with lower pain sensitivity (FREIRE and GONÇALVES 2013). Although this practice maintains the quality of the meat after slaughter, it is stressful because the fish suffers from water acidification caused by $\mathrm{CO}_{2}$ saturation, which is dissolved, giving rise to $\mathrm{H}_{2} \mathrm{CO}_{3}$ in balance with $\mathrm{HCO}_{3}$ and $\mathrm{H}+$, indicated by a quick reaction of attempted escape.

Studies show that the response of Atlantic salmon (Salmo salar) to the acidic and hypoxic environment causes acute stress and attempted escape, leading to a rapid state of rigor mortis and, consequently, to early muscle flaccidity (VIEGAS et al., 2012). According to Freire and Gonçalves (2013), hypothermia in animals leads to stunning and is assessed on welfare issues along with final meat quality.

Electric shock is used for both stunning and slaughter (VIEGAS et al., 2012), and it is applied to the animal's head (FREIRE and GONÇALVES 2013), promoting a rapid transition to stunning, being executed individually or in batches. This technique is used in fish species such as herring (Clupea harengus), common carp (Cyprinus carpio), grass carp (Ctenopharyngodon idella), sea bass (Dicentrarchus labrax), salmon (Salmo salar), African catfish (Clarias gariepinus), eel (Anguilla anguilla), sea bream (Sparus aurata), Nile tilapia (Oreochromis niloticus), turbot (Psetta maxima) and 
rainbow trout (Oncorhynchus mykiss) (VIEGAS et al., 2012). According to analyses of behavioral data and brain reflexes, it causes less disturbance to animals (FREIRE and GONÇALVES 2013).

The correct voltage, frequency, type of electric current, and exposure time for each fish species need to be observed because a very strong or inadequately applied electric current can cause bone breakage and hemorrhages, which will compromise the quality of the fillets. African catfish (Clarias gariepinus) submitted to electric shock for 5 seconds showed loss of consciousness without recovery. The immediate stunning and immobility of Atlantic salmon (Salmo salar) is done by adopting alternating current, decreasing average handling (VIEGAS et al., 2012).

The method of a lethal blow to the head is done with a posterior cut to the gills, and then the head is separated from the body (FERREIRA et al., 2018). The bone marrow section is performed by a sharp knife introduced into one of the opercula of the fish (FERREIRA et al., 2018) up to the marrow. This method was considered the most insensitive to pain, keeping meat within protein quality standards and not significantly different from other slaughter methods (FREIRE and GONÇALVES 2013).

\section{Conclusion}

Acceptable methods of slaughter must render animals insensitive immediately and must be performed without causing undue pain or suffering. Traditional methods of stunning used for fish slaughter are the electrical method, electrocution, bone marrow section, and the lethal blow to the head.

The type of slaughter method affects not only welfare but also meat quality. The recognition of suffering also endorses humane slaughter regulations to reduce pain in a large number of fish that are slaughtered annually for human consumption. 


\section{Contradições e desafios do abate de peixes no Brasil}

Resumo: A piscicultura é uma atividade de extrema importância para o mercado brasileiro, visto que atualmente está em grande ascensão. Para a obtenção de produtos de alta qualidade são necessários alguns cuidados desde a criação, envolvendo instalações, alimentação adequada, manejo, despesca, abate e acondicionamento. Na cadeia da piscicultura, um dos momentos mais importantes é o abate, pois é quando o produto sofre modificações que interferem em sua qualidade final, considerando aspecto, odor, textura e a palatabilidade. No Regulamento de Inspeção Industrial e Sanitária de Produtos de Origem Animal (RIISPOA) há poucas informações que se referem ao abate do pescado, principalmente sobre a maneira adequada que deve ser realizado, enquanto na Instrução Normativa $\mathrm{N}^{\mathrm{o}}$ 3, do Ministério da Agricultura, Pecuária e Abastecimento (MAPA), de 17 de janeiro de 2000, determina-se a padronização dos métodos de insensibilização para o abate humanitário em várias espécies animais, exceto para o pescado. De acordo com esta revisão bibliográfica, a insensibilização por eletrocussão, o golpe letal na cabeça e a secção de medula são as melhores técnicas para serem utilizadas, porém ainda faltam estudos para sua padronização. Por esse motivo, este trabalho reúne informações sobre o abate do pescado, bem como ressalta a necessidade de regulamentação pelos órgãos pertinentes.

Palavras-chave: bem-estar animal, legislação sanitária, piscicultura, pescado, qualidade.

\section{References}

ANDRADE, D.R.; YASUI, G.S. Natural and Artificial Breeding Management and Its Importance in Fish Production in Brazil. Rev. Bras. Reprod. Animal, v. 27, n. 2, p. 166-172, 2003.

BRASIL. Instrução normativa $\mathrm{n}^{0} 3$, de 17 de janeiro de 2000. Regulamento técnico de métodos de insensibilização para o abate humanitário de animais de açougue. Brasília, 2000. Disponível em: <http://www.agricultura.gov.br/assuntos/sustentabilidade/bemestar-animal/arquivos/arquivos-legislacao/in-03-de-2000.pdf>. Acesso em: 03 nov. 2018. 
BRASIL. Decreto n. 9.013, de 29 de março de 2017. Brasília, 2017. Presidência da República. Disponível

em:

$<$ http://legislacao.planalto.gov.br/legisla/legislacao.nsf/Viw Identificacao/DEC \%209.013-2017? OpenDocument>. Acesso em: 02 nov. 2018.

BRASIL. Modernização do RIISPOA. Brasília, 2017. Disponível em: $<$ http://www.agricultura.gov.br/assuntos/inspecao/produtos-animal/modernizacaodo-riispoa>. Acesso em: 03 nov. 2018.

CHICRALA, P.C.M.S.; SANTOS, V.R.V. Despesca e abate de peixes. In: EMBRAPA Piscicultura de água doce: multiplicando conhecimentos. Embrapa, 2013. cap. 11, p. 379-397.

CREPALDI, D.V.; TEIXEIRA, E.A.; FARIA, P.M.C.; RIBEIRO, L.P.; MELO, D.C.; CARVAlHO, D, SOUSA, A.B.; SATURNINO, H.M. Sistemas de produção na piscicultura. Rev. Bras. Reprod. Anim. v. 30, n. 3/4, p. 86-99. 2006.

FOOD AND AGRICULTURE ORGANIZATION. Pesca e Aquicultura. Roma, 2006. Disponível em: <http://www.fao.org/docrep/012/i0765pt/i0765pt09.pdf $>$. Acesso em: 02 nov. 2018.

FOOD AND AGRICULTURE ORGANIZATION. Pesca e Aquicultura. Roma, Itália, 2006. Disponível em: <http://www.fao.org/docrep/012/i0765pt/i0765pt09.pdf $>$. Acesso em: 15 nov. 2018.

FERREIRA, N.A.; ARAÚJO, R.V.; CAMPOS, E.C. Boas práticas no pré-abate e abate de pescado. PUBVET, v. 12, n. 7, a137, p.1-14, 2018. https://doi.org/10.31533/pubvet.v12n7a137.1-14

FREIRE, C.E.C.; GONÇALVES, A.A. Diferentes métodos de abate do pescado produzido em aquicultura, qualidade da carne e bem-estar do animal. Holos, v. 6, 2013. https://doi.org/10.15628/holos.2013.992 
KUBITZA, F. Mais profissionalismo no transporte de peixes vivos. Panorama da Aqüicultura, Rio de Janeiro, dez. 2007. Disponível em: $<$ https://panoramadaaquicultura.com.br/mais-profissionalismo-no-transporte-depeixes-vivos/>. Acesso em: 01 nov. 2018.

LAMBOOIJ, E.A.; VIS.J.W.V.; KLOOSTERBOER, R.J.; PIETERSE, C. Welfare aspects of live chilling and freezing of farmed eel (Anguilla anguilla L.): neurological and behavioural assessment. Aquaculture, v. 210, n. 1-4, p. 159-169, 2002. https://doi.org/10.1016/S0044-8486(02)00050-9

LOPES, J.C.O. Piscicultura. Sistema Escola Técnica Aberta do Brasil. Floriano, jan. 2010 .

Disponível

em: $<$ http://pronatec.ifpr.edu.br/wp-content/uploads/2013/06/Piscicultura.pdf $>$. Acesso em: 05 nov. 2018.

MENDES, J.M.; INOUE, L.A.K.; JESUS, R.S. Influence of transport stress and slaughter method on rigor mortis of tambaqui (Colossoma macropomum). Braz. J. Food Technol., v. 18, n. 2, p. 162-169, 2015. https://doi.org/10.1590/1981-6723.1115

PEDRAZZANI, A.S.; MOLENTO, C.F.; CARNEIRO, P.C.F.; FERNANDES-DECASTILHO, M. Senciência e bem-estar de peixes: uma visão de futuro do mercado consumidor. Panorama da Aqüicultura, Rio de Janeiro, ago. 2007. Disponível em: $<$ https://panoramadaaquicultura.com.br/senciencia-e-bem-estar-de-peixes-umavisao-de-futuro-do-mercado-consumidor/>. Acesso em: 01 nov. 2018.

PEIXEBR - ANUÁRIO PEIXE BR DA PISCICULTURA 2020. Associação Brasileira de Piscicultura. 2020. Disponível em: <https://www.peixebr.com.br/anuario-2020/>. Acesso em: 28 abril 2020.

SEBRAE. A evolução da piscicultura no Brasil. 2015. Disponível em: $<$ http://www.sebraemercados.com.br/a-evolucao-da-piscicultura-no-brasil/>. Acesso em: 10 nov. 2018. 
VIEGAS, E.M.M.; PIMENTA, F.A.; PREVIERO, T.C.; GONÇALVES, L.U.; DURÃES, J.P.; RIBEIRO, M.A.R.; OLIVEIRA FILHO, P.R.C. Slaughter methods and fish meat $\begin{array}{llllll}\text { quality. Arch. ZOOTECNIA. v. } & \text { v1, } & \text { p. } & 41-50,\end{array}$ https://doi.org/10.21071/az.v61i237.2957

WORLD ORGANISATION FOR ANIMAL HEALTH. Capítulo 7.2. Bem-estar dos peixes de cultivo durante o transporte. Código Sanitário de Animais Aquáticos da OIE. Paris, 2012. Disponível em: <http://www.oie.int/index.php?

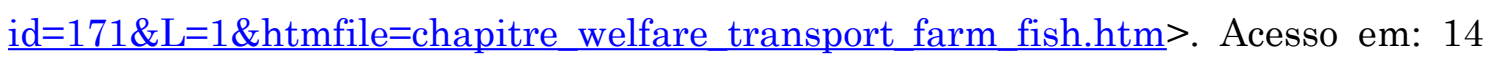
nov. 2018.

WORLD ORGANISATION FOR ANIMAL HEALTH. Capítulo 7.3. Aspectos de bem-estar animal relacionados a insensibilização e abate de peixes provenientes de criatórios destinados ao consumo humano. Código Sanitário de Animais Aquáticos da OIE. Paris, 2012. Disponível em: <http://www.oie.int/index.php?


2018. 